Original research article

\title{
Depression and anxiety as predictors of quality of life after a stroke
}

\author{
Tomáš Sollár ${ }^{1 *}$, Katarína Dančová ${ }^{2}$, Andrea Solgajová ${ }^{3}$, Martina Romanová ${ }^{2}$ \\ ${ }^{1}$ Constantine the Philosopher University in Nitra, Faculty od Social Sciences and Health Care, Department of Psychological Sciences, Nitra, \\ Slovak Republic \\ ${ }^{2}$ Constantine the Philosopher University in Nitra, Faculty od Social Sciences and Health Care, Institute of Applied Psychology, Nitra, Slovak Republic \\ ${ }^{3}$ Constantine the Philosopher University in Nitra, Faculty od Social Sciences and Health Care, Department of Nursing, Nitra, Slovak Republic
}

\begin{abstract}
Introduction: Evaluating quality of life in stroke patients is an essential part of treatment. Quality of life can be predicted not only by the physical disability after a stroke, but also by the patient's psychosocial state. The aim of the present study is to examine the relationship between depression, anxiety, and quality of life in the acute phase after strokes.

Methods: A cross-sectional descriptive type of study was carried out. The research sample consisted of 79 patients after a stroke $\left(\mathrm{M}_{\text {age }}=\right.$ $67.9 \pm 12.3$ ). Depression and anxiety were measured using the Hospital Anxiety and Depression Scale, and quality of life using the Stroke Specific Quality of Life Scale. Simple and multiple linear regression analyses were used for data analysis.

Results: Depression and anxiety predicted overall quality of life in patients after a stroke. The physical aspect of quality of life and overall quality of life were strongly predicted by depression, while the psychosocial aspect of quality of life was strongly related to anxiety in stroke patients. Higher depression and anxiety are manifested in a worsened quality of life, and it is similar in the physical and psychosocial aspects. Approximately $20 \%$ of patients had severe depression and anxiety.

Conclusions: A patient's quality of life after a stroke is affected not only by their functional condition, but also by psychosocial distress. Early diagnostics of psychosocial distress should be an important part of the care and treatment of stroke patients.
\end{abstract}

Keywords: Anxiety; Depression; Quality of life; Stroke

\section{Introduction}

A stroke affects multiple areas of a person's life. Social, family, physical, emotional areas, and work habits are most affected (Akinpelu et al., 2012; Akosile et al., 2013; Dimunová et al., 2021; Enato et al., 2011; Hamza et al., 2014). Depression and anxiety are reported as common consequences after strokes, and have a direct impact on patients' quality of life (Donnellan et al., 2010). According to several authors, depression and anxiety after a stroke can affect patients' levels of functional independence, cognitive and social functioning, and overall quality of life (Ayerbe et al., 2013; Peixoto et al., 2017). Depression after a stroke occurs in the acute phase in approximately a quarter of patients. It is present one (Hackett et al. 2005) to five years after the stroke (Hackett and Pickles, 2014). Depression after a stroke negatively affects the process of convalescence. It may complicate the success of rehabilitation, reduce a positive prognosis of the disease, and condition the level of autonomous functioning of the patient (Kouwenhoven et al., 2011). Patients suffering from depression have lower levels of cogni- tive functions and report greater problems with their physical condition. In general, the prognosis of the disease is poorer in these patients, thus prolonging the time of recovery of impaired functions. The quality of life is also significantly lower. Symptoms of depression increase the risk of mortality within two years from first stroke attack (Thomas and Lincoln, 2006).

Anxiety after a stroke occurs in approximately $16-29 \%$ of patients (Barker-Collo, 2007; Lincoln et al., 2013), and is described as one of the most common mood disorders in stroke patients. Patients suffering from anxiety symptoms have lower quality of life, are more likely to seek health care, and have a higher risk of deteriorating health, regardless of the objective indicators of their health (Burton et al., 2013). Patients recovering from a stroke and suffering from anxiety experience concerns related to the recurrence of the brain disease or doubts about their ability to return to work (Watanabe, 2005). Furthermore, anxiety seems to be an independent determinant of reduced quality of life in the acute and subacute phases of the stroke brain disease (Donnellan et al., 2010).

In the present study, we examine overall quality of life, and separately the physical and psychosocial areas of quality of life

\footnotetext{
* Corresponding author: Tomáš Sollár, Constantine the Philosopher University in Nitra, Faculty of Social Sciences and Health Care, Department of Psychological Sciences, Kraskova 1, 94974 Nitra, Slovak Republic; e-mail: tsollar@ukf.sk http://doi.org/10.32725/kont.2022.002
} 
in relation to depression and anxiety in stroke patients. The study is of a verification and exploration nature. We assume that anxiety and depression are negatively related to quality of life (research hypothesis). However, are both psychological variables (anxiety and depression) related to two aspects of quality of life (physical and psychosocial) equally (research question)?

\section{Materials and methods}

\section{Sample}

A cross-sectional descriptive study type was used. The research involved 79 hospitalized patients, i.e. 59\% of all hospitalized stroke patients in the studied period at a selected neurological clinic (an intensive care unit and a treatment unit). The inclusion criteria were: (1) The medical diagnosis of a stroke, diagnosed on the basis of a finding on computed tomography (CT) or magnetic resonance imaging (MRI) and on the presence of symptomatology; (2) Lucid consciousness; (3) An ability to communicate; (4) Hospitalization occurred no later than the 5th day after the stroke; (5) Age $\geq 18$ years; (6) NIHSS (National Institutes of Health Stroke Scale) score 21 ; and (7) An expressed informed consent. The exclusion criteria were: (1) Other severe diseases (cancer, dementia, etc.) that could affect outcomes; (2) Impaired consciousness and an inability to communicate; and (3) Death. The average age of the patients was 67.9 years $\left(\mathrm{SD}_{\text {age }}=12.3\right)$. Out of the total number of the patients, $65 \%$ were male, and ischaemic stroke had the highest incidence (86\%). Severe levels of depression were reported by $20 \%$ of the patients, and severe levels of anxiety were reported by $25 \%$. Additional demographic and clinical characteristics are shown in Table 1. Data collection took place from August to October 2020. The study was approved by the hospital's Ethics Committee.

\section{Methods}

Depression and anxiety were measured by the Hospital Anxiety and Depression Scale (HADS; Zigmond, Snaith, 1983). The questionnaire contains 14 items; it consists of two subscales HADS-A (anxiety) and HADS-D (depression). Seven items focus on anxiety assessment and seven on depression assessment. The respondent answers each item using the Likert-type scale from 0 to 3 , in relation to how he/she felt during the previous week (during hospitalization). A raw score was used for analysis purposes. The maximum score is 21 points; the scores 0-7 mean the norm, 8-10 borderline level, and 11-21 severe level of anxiety or depression (McDowell, 2006). The internal consistency of the scales is: HADS-A $\alpha=0.71$, and HADS-D $\alpha=0.64$.

The short version of the Stroke Specific Quality of Life Scale (SS-QoL-12; Post et al., 2011) was used to assess quality of life in stroke patients. The questionnaire contains 12 items: (a) Self-care, (b) Mobility, (c) Upper extremity function, (d) Language, (e) Vision, (f) Work, (g) Thinking, (h) Family roles, (i) Social roles, (j) Personality, (k) Mood, and (l) Energy. The items from $a$ to $f$ refer to physical quality of life, and the items from $g$ to $l$ refer to psychosocial quality of life. Respondents answer questions on the scales from 1 - Couldn't do it at all, to 5 - No trouble at all, and from 1 - Strongly agree, to 5 - Strongly disagree. Higher scores indicate a higher level of quality of life. In the present study, the resulting internal consistency values of the SS-QoL-12 confirm its adequate internal consistency for overall quality of life $(\alpha=0.87)$, also for physical quality of life $(\alpha=0.86)$ and psychosocial quality of life
Table 1. Demographic and clinical characteristics of

respondents

\begin{tabular}{|c|c|c|}
\hline & $n$ & $\%$ \\
\hline \multicolumn{3}{|l|}{ Gender $(n=79)$} \\
\hline Men & 51 & 64.6 \\
\hline Women & 28 & 35.4 \\
\hline \multicolumn{3}{|l|}{ Education $(n=79)$} \\
\hline Primary school & 7 & 8.8 \\
\hline Secondary school & 62 & 78.5 \\
\hline University & 10 & 12.7 \\
\hline \multicolumn{3}{|l|}{ Living situation $(n=79)$} \\
\hline Living with someone & 61 & 77.2 \\
\hline Living alone & 18 & 22.8 \\
\hline \multicolumn{3}{|l|}{ Stroke aetiology $(n=79)$} \\
\hline Ischaemic & 68 & 86.0 \\
\hline Haemorrhagic & 6 & 7.6 \\
\hline Unknown & 5 & 6.3 \\
\hline \multicolumn{3}{|l|}{ Lesion $(n=79)$} \\
\hline Right hemisphere & 34 & 43.0 \\
\hline Left hemisphere & 45 & 57.0 \\
\hline Severity of stroke after four days $(n=79)$ & \multicolumn{2}{|c|}{$3.8 \pm 3.1$} \\
\hline No symptoms & 7 & 8.9 \\
\hline Mild stroke symptoms & 50 & 63.3 \\
\hline Moderate stroke symptoms & 20 & 25.3 \\
\hline Severe stroke symptoms & 2 & 2.5 \\
\hline BMI $(n=79)$ & \multicolumn{2}{|c|}{$27.2 \pm 5.1$} \\
\hline Barthel index $(n=79)$ & \multicolumn{2}{|c|}{$59.0 \pm 34.4$} \\
\hline No dependency & 16 & 20.3 \\
\hline Low dependency & 30 & 38.0 \\
\hline Moderate dependency & 14 & 17.7 \\
\hline High dependency & 19 & 24.1 \\
\hline $\operatorname{MMSE}(n=79)$ & \multicolumn{2}{|c|}{$20.7 \pm 4.9$} \\
\hline Norm & 25 & 31.7 \\
\hline Mild cognitive impairment & 19 & 24.0 \\
\hline Moderate cognitive impairment & 33 & 41.8 \\
\hline Severe cognitive impairment & 2 & 2.5 \\
\hline Depression $(n=79)$ & \multicolumn{2}{|c|}{$7.42 \pm 3.22$} \\
\hline Norm & 43 & 54.4 \\
\hline Borderline & 20 & 25.3 \\
\hline Severe & 16 & 20.3 \\
\hline Anxiety $(n=79)$ & \multicolumn{2}{|c|}{$8.66 \pm 3.47$} \\
\hline Norm & 32 & 40.5 \\
\hline Borderline & 27 & 34.2 \\
\hline Severe & 20 & 25.3 \\
\hline
\end{tabular}

$(\alpha=0.70)$. When using a short version of the scale (SS-QoL-12), it is recommended to use two factors and an overall score (Chou et al., 2017; Post et al., 2011).

\section{Data analysis}

The IBM SPSS Statistics 21 programme was used for data analysis. To test the relationship between depression, anxiety, and quality of life, we used the methods of linear regression analysis; in the case of one independent variable, a simple linear regression was used; in the case of two predictors, the multiple linear regression analysis (the Enter method) was used. The data met the conditions for the use of regression analysis. The data included no outliers. Autocorrelations in the residuals of dependent variables were detected by the Durbin-Watson test, with the values ranging from 1.99 to 2.14 , which means meet- 
ing the assumption of independence in the data. The data met the conditions for normal distribution, with skewness values between -0.20 and 0.60 , and kurtosis values between -1.22 and -0.25 (Tabachnick and Fidell, 2017).

\section{Results}

The results answer the question on examining the predictors of quality of life in stroke patients. In the first part, the findings on the relationship between quality of life and depression and anxiety are presented separately, in the second part in combination. Three indicators of quality of life were evaluated: physical quality of life, psychosocial quality of life, and overall quality of life.

\section{Depression as a predictor of quality of life}

Depression explains $37.8 \%$ of the variability of overall quality of life in stroke patients. The relationship between depression and quality of life is negative and strong $(\beta=-0.615)$. Depression explains the physical aspect of quality of life $(43.8 \%$; $\beta=-0.662$ ) to a greater extent than the psychosocial aspect $(20.0 \% ; \beta=-0.447)$. All the results are statistically significant $(p<0.001)$ - Table 2.

Table 2. Regression models for prediction of quality of life and depression in stroke patients

\begin{tabular}{lcccccc} 
& $R_{2}$ & $F$ & B & SE(B) & $\beta$ & $t$ \\
\hline Depression $\rightarrow$ QoL_Physical & 0.438 & $60.02^{* * *}$ & -0.185 & 0.024 & -0.662 & $7.75^{* * *}$ \\
\hline Depression $\rightarrow$ QoL_Psychosocial & 0.200 & $19.19^{* * *}$ & -0.098 & 0.022 & -0.447 & $4.38^{* * *}$ \\
Depression $\rightarrow$ QoL & 0.378 & $46.88^{* * *}$ & -0.141 & 0.021 & -0.615 & $6.85^{* * *}$ \\
\hline
\end{tabular}

Legend: $R_{2}$ - coefficient of determination, $F$ - Fisher's F-test, B - unstandardized regression coefficient, $\mathrm{SE}(\mathrm{B})$ - standard error of unstandardized regression coefficient, $\beta$-standardized regression coefficient, $t-t$-statistic, ${ }^{* * *} p<0.001$.

\section{Anxiety as a predictor of quality of life}

Anxiety explains $29.6 \%$ of the variability of overall quality of life in stroke patients. The relationship between anxiety and quality of life is negative and strong $(\beta=-0.544)$. Anxiety ex- plains both aspects of quality of life equally strongly (physical: $25.7 \% ; \beta=-0.506$; psychosocial: $24.5 \% ; \beta=-0.495)$. All the results are statistically significant $(p<0.001)$ - Table 3 .

Table 3. Regression models for prediction of quality of life and anxiety in stroke patients

\begin{tabular}{|c|c|c|c|c|c|c|}
\hline & $R_{2}$ & $F$ & $\mathrm{~B}$ & $\mathrm{SE}(\mathrm{B})$ & $\beta$ & $t$ \\
\hline Anxiety $\rightarrow$ QoL_Physical & 0.257 & $25.57^{* * *}$ & -0.131 & 0.025 & -0.506 & $5.15^{* * *}$ \\
\hline Anxiety $\rightarrow$ QoL_Psychosocial & 0.245 & $24.97^{* * *}$ & -0.101 & 0.020 & -0.495 & $5.00^{* * *}$ \\
\hline Anxiety $\rightarrow$ QoL & 0.296 & $32.36^{* * *}$ & -0.116 & 0.020 & -0.544 & $5.69^{* * *}$ \\
\hline
\end{tabular}

Legend: $R_{2}$ - coefficient of determination, $F$ - Fisher's F-test, B - unstandardized regression coefficient, $\mathrm{SE}(\mathrm{B})$ - standard error of unstandardized regression coefficient, $\beta$ - standardized regression coefficient, $t-t$-statistic, ${ }^{* * *} p<0.001$.

\section{Depression and anxiety as predictors of quality of life}

Overall quality of life in stroke patients is explained by both predictors statistically significantly $(F=32.36, p<0.001$; overall proportion of explained variance $46.0 \%$ ). The relationship between quality of life and both predictors is negative and moderate (anxiety $\beta=-0.325$, depression $\beta=-0.461$ ).

The physical aspect of quality of life in stroke patients is explained equally by the two predictors statistically significantly $(F=35.84, p<0.001$; overall proportion of explained variance
$48.5 \%)$. The relationship between quality of life and both predictors is negative (anxiety $\beta=-0.247$, depression $\beta=-0.544$ ).

The psychosocial aspect of quality of life in stroke patients is explained by both predictors statistically significantly $(F=16.48, p<0.001$; overall proportion of explained variance $30.2 \%$ ). The relationship between quality of life and both predictors is negative (anxiety $\beta=-0.365$, depression $\beta=-0.273)$ - Table 4 .

Table 4. Regression models for prediction of quality of life in stroke patients

\begin{tabular}{|c|c|c|c|c|c|c|}
\hline & $R_{2}$ & $F$ & B & $\mathrm{SE}(\mathrm{B})$ & $\beta$ & $t$ \\
\hline QoL_Physical & 0.485 & $35.84^{* * *}$ & & & & \\
\hline Anxiety & & & -0.064 & 0.024 & -0.247 & $2.64^{*}$ \\
\hline Depression & & & -0.152 & 0.026 & -0.544 & $5.81^{* * *}$ \\
\hline QoL_Psychosocial & 0.302 & $16.48^{* * *}$ & & & & \\
\hline Anxiety & & & -0.074 & 0.022 & -0.365 & $3.35^{* *}$ \\
\hline Depression & & & -0.060 & 0.024 & -0.273 & $2.50^{*}$ \\
\hline QoL & 0.460 & $32.36^{* * *}$ & & & & \\
\hline Anxiety & & & -0.069 & 0.020 & -0.325 & $3.39^{* *}$ \\
\hline Depression & & & -0.106 & 0.022 & -0.461 & $4.80^{* * *}$ \\
\hline
\end{tabular}

Legend: $R_{2}$ - coefficient of determination, $F$ - Fisher's $F$-test, B - unstandardized regression coefficient, $S E(B)$ - standard error of unstandardized regression coefficient, $\beta$ - standardized regression coefficient, $t$ - $t$-statistic, ${ }^{*} p<0.05,{ }^{* *} p<0.01,{ }^{* * *} p<0.001$. 


\section{Discussion}

Health-Related Quality of Life (HRQOL) and subjective well-being are indicators that have been increasingly integrated into health care evaluation (Donellan, et al., 2010; Peixoto et al., 2017; Tóthová et al., 2014).

Anxiety and depression as predictors of quality of life in stroke patients have been less studied than other predictors, such as demographic or clinical ones. Some studies also suggest studying anxiety, depression, and other predictors of quality of life after stroke together. According to Boudokhane et al. (2021), stroke severity, depression, disability, and advanced age consistently predict reduced levels of quality of life. The physical aspect of quality of life is mainly related to age, stroke assessment in accordance with the NIHSS, and motor deficit. The psychosocial aspect of quality of life is mainly related to depression, left-sided lesion in stroke, and an ability to perform activities of daily living.

In addition to the stated predictors, other authors (Sadlonova et al., 2020) also describe the effects of gender on quality of life in stroke patients. Lower quality of life in women after stroke is represented by a worse assessment of mobility and the ability to perform activities of daily living. The authors (Sadlonova et al., 2020) state that lower quality of life in women can likely be explained by higher levels of anxiety compared to men. The authors recommend that future research should also focus on evaluation of the effects of anxiety on quality of life in stroke patients.

Depression and anxiety after stroke affect overall quality of life (Ayerbe et al., 2013; Peixoto et al., 2017). We assumed that anxiety and depression are negatively related to quality of life. The analyses were carried out for depression and anxiety separately, and in combination. The study results support the statement.

Depression occurs in stroke patients as early as the acute phase of the disease in about a quarter of patients (Hackett et al. 2005; Mayo et al., 2002; Selvaraj et al., 2021). In the sample of the present study, according to the HADS-D, severe levels of depression occurred in approximately $20 \%$ of the patients. Depression predicts poorer overall quality of life. The same relationship occurs in both studied areas: physical and psychosocial, while a stronger relationship was found with the physical aspect of quality of life. The result may be explained in accordance with the authors (Berg et al., 2001), who report that depression is one of the important determinants affecting the functional state of patients. Untreated depression may have negative effects on rehabilitation and other aspects of quality of life in stroke patients (Dafer et al., 2008, Selvaraj et al., 2021).

Furthermore, anxiety seems to be a determinant of reduced quality of life in the acute and subacute phases of brain diseases (Donnellan et al., 2010). Approximately 16-29\% of stroke patients experience anxiety (Barker-Collo, 2007; Lincoln et al., 2013; Rafsten et al., 2018). In the present study, according to the HADS-A, severe levels of anxiety occurred in approximately $25 \%$ of the patients, which is consistent with the previous studies. Anxiety predicts poorer overall quality of life, equally strong in both physical and psychosocial areas. Patients recovering from a stroke and suffering from anxiety experience concerns related to the recurrence of the brain disease or doubts about their ability to return to work (Watanabe, 2005).
In the case of analysis of the combination of predictors (depression and anxiety) of quality of life, it appears that both significantly reduce quality of life. Depression and anxiety separately explain $37.8 \%$ and $29.6 \%$ of the variability of quality of life, respectively. Together, depression and anxiety explain $46 \%$ of the variability of quality of life in stroke patients. The information above suggests that the combination of predictors significantly worsens the quality of life in stroke patients. Based on this finding, we can conclude that psychosocial state has a significant impact on the evaluation of quality of life in stroke patients. Thus, we support the findings of the authors (Darlington et al., 2007) that it is not only the functional state, but also the psychosocial state, that has an impact on the evaluation of quality of life. Furthermore, (Darlington et al., 2007) state that patients with a minimal physical disability or without a physical disability also report reduced quality of life, which may be related only to their psychosocial state. The authors (Rachpukdee et al., 2013) state that stroke patients still experience psychosocial stress three months after overcoming the disease, and improvements tend to occur in the physical rather than psychosocial domain. Therefore, they also recommend caring for both the physical and psychosocial aspects of a stroke in the overall treatment (Rachpukdee et al., 2013; Towfighi et al., 2017).

One limitation of the present study is its cross-sectional design; on the other hand, it corresponds to the specified research problem. Another limitation is the sample size and the measuring instruments - which were of a self-assessment nature. Further research into the relationship between quality of life and depression and anxiety in stroke patients needs to be extended into areas such as longitudinal monitoring and the effectiveness of appropriate interventions.

\section{Conclusions}

Depression in stroke patients predicts poorer overall quality of life to a larger extent than anxiety. Quality of life in stroke patients shows a strong negative relationship with both variables of psychological experience (anxiety and depression). Depression affects the physical aspect of life more, while anxiety affects both physical and psychosocial aspects of quality of life. The implication of the present study for improving the care for stroke patients is knowledge of the interaction of both psychological states (anxiety and depression) at the same time. Together, depression and anxiety explain almost half of the variability of quality of life in stroke patients. If present, they mainly negatively affect the physical aspect of quality of life in stroke patients. Consequently, this negatively affects the success of rehabilitation focused on problems with physical condition and prognosis of the disease. Quality of life evaluation, together with early diagnosis of psychosocial state in stroke patients, is an essential part of care and treatment.

\section{Ethical aspects and conflict of interests}

The authors have no conflict of interests to declare.

\section{Funding}

The paper was supported by the VEGA project 1/0418/19 Coping strategies in recovery after stroke. 


\section{Depresia a úzkost' ako prediktory kvality života po cievnej mozgovej príhode}

\section{Súhrn}

Úvod: Hodnotenie kvality života u pacientov po prekonaní cievnej mozgovej príhody (CMP) je nevyhnutnou súčasṫou liečby. Kvalitu života predikujú nielen telesné postihnutie po CMP, ale aj psychosociálny stav pacienta. Ciel'om štúdie je zistit' vzt'ah medzi depresiou, úzkostou a kvalitou života v akútnej fáze po prekonaní CMP.

Metódy: Výskum bol realizovaný ako prierezová deskriptívna štúdia. Výskumnú vzorku tvorilo 79 pacientov po $C M P\left(M_{\text {vek }}=\right.$ $67,9 \pm 12,3)$. Depresia a úzkost' boli merané prostredníctvom dotazníka Hospital Anxiety and Depression Scale a kvalita života dotazníkom Stroke Specific Quality of Life Scale . Dáta boli analyzované jednoduchou a viacnásobnou lineárnou regresiou. Výsledky: Depresia a úzkost' predikujú celkovú kvalitu života pacientov po CMP štatisticky významne. Fyzický aspekt kvality života a celkovú kvalitu života viac predikuje depresia, naopak psychosociálny aspekt kvality života viac súvisí s úzkostou pacientov po prekonaní CMP. Vyššia depresia aj úzkost' sa prejavujú v zhoršenej kvalite života, obdobne vo fyzickom aj psychosociálnom aspekte. Závažnú mieru depresie a úzkosti vykazovalo približne $20 \%$ pacientov.

Záver: Na kvalitu života pacienta po prekonaní CMP má vplyv nielen jeho funkčný stav, ale aj psychosociálny distres. Včasná diagnostika psychosociálneho distresu by mala byt dôležitou súčastou starostlivosti a liečby pacientov po CMP.

Kl'účové slová: cievna mozgová príhoda; depresia; kvalita života; úzkost'

\section{References}

1. Akinpelu AO, Odetunde MO, Odole AC (2012). Cross-cultural adaptation and initial validation of the Stroke-Specific Quality of Life Scale into the Yoruba language. Int J Rehabil Res 35(4): 339-344. DOI: 10.1097/MRR.0b013e328355dd54.

2. Akosile CO, Adegoke B, Ezeife CA, Maruf FA, Ibikunle PO, Johnson OE, Dada OO (2013). Quality of life and sexdifferences in a south-eastern Nigerian stroke sample. Afr J Neurol Sci 32(1): 19-25.

3. Ayerbe L, Ayis S, Wolfe CD, Rudd AG (2013). Natural history, predictors and outcomes of depression after stroke: systematic review and meta-analysis. Br J Psychiatry 202(1): 14-21. DOI: 10.1192/bjp.bp.111.107664.

4. Barker-Collo SL (2007). Depression and anxiety 3 months post stroke: prevalence and correlates. Arch Clin Neuropsychol 22(4): 519-531. DOI: 10.1016/j.acn.2007.03.002.

5. Berg A, Palomäki H, Lehtihalmes M, Lönnqvist J, Kaste M (2001). Poststroke depression in acute phase after stroke. Cerebrovasc Dis 12(1): 14-20. DOI: 10.1159/000047675.

6. Boudokhane S, Migaou H, Kalai A, Jellad A, Borgi O, Bouden A, et al. (2021). Predictors of Quality of Life in Stroke Survivors: A 1-year Follow-Up Study of a Tunisian Sample. J Stroke Cerebrovasc Dis 30(4): 105600, DOI: 10.1016/j. jstrokecerebrovasdis.2021.105600.

7. Burton CAC, Murray J, Holmes J, Astin F, Greenwood D, Knapp P (2013). Frequency of anxiety after stroke: a systematic review and meta-analysis of observational studies. Int J Stroke 8(7): 545-559. DOI: 10.1111/j.1747-4949.2012.00906.x.

8. Chou C-Y, Huang C-Y, Huang Y-J, Lin G-H, Huang S-L, Lee S-C, Hsieh C-L (2017). Comparison of construct validity of two short forms of Stroke-Specific Quality of Life scale. PLoS One 12(12): e0188478. DOI: 10.1371/journal.pone.0188478.

9. Dafer RM, Rao M, Shareef A, Sharma A (2008). Poststroke depression. Top Stroke Rehabil 15(1): 13-21. DOI: 10.1310/ tsr1501-13.

10. Darlington AS, Dippel DW, Ribbers GM, van Balen R, Passchier J, Busschbach JJ (2007). Coping strategies as determinants of quality of life in stroke patients: a longitudinal study. Cerebrovasc Dis 23(5-6): 401-407. DOI: $10.1159 / 000101463$.

11. Dimunová L, Sováriová Soósová M, Kardosová K, Červený M, Belovičová M (2021). Quality of life in post-stroke patients. Kontakt 22(3): 157-161. DOI: 10.32725/kont.2020.036.

12. Donnellan C, Hickey A, Hevey D, O'Neill D (2010). Effect of mood symptoms on recovery one year after stroke. Int J Geriatr Psychiatry 25(12): 1288-1295. DOI: 10.1002/ gps.2482.
13. Enato EFO, Yovwin EO, Ogunrin OA (2011). Assessment of health-related quality of life in stroke survivors attending two healthcare facilities in Benin City, Nigeria. JPB 8(1): 54-60. DOI: $10.4314 / j p b . v 8 i 1.9$.

14. Hackett ML, Pickles K (2014). Part I: frequency of depression after stroke: an updated systematic review and meta-analysis of observational studies. Int J Stroke 9(8): 1017-1025. DOI: 10.1111/ijs.12357.

15. Hackett ML, Yapa C, Parag V, Anderson CS (2005). Frequency of depression after stroke: a systematic review of observational studies. Stroke 36(6): 1330-1340. DOI: 10.1161/01. STR.0000165928.19135.35.

16. Hamza AM, Al-Sadat N, Loh SY, Jahan NK (2014). Predictors of poststroke health-related quality of life in Nigerian stroke survivors: a 1-year follow-up study. Biomed Res Int 2014 350281. DOI: $10.1155 / 2014 / 350281$.

17. Kouwenhoven SE, Kirkevold M, Engedal K, Kim HS (2011). Depression in acute stroke: prevalence, dominant symptoms and associated factors. A systematic literature review. Disabil 33(7): 539-556. DOI: 10.3109/09638288.2010.505997.

18. Lincoln NB., Brinkmann N, Cunningham S, Dejaeger E, De Weerdt W, Jenni W, et al. (2013). Anxiety and depression after stroke: a 5 year follow-up. Disabil 35(2): 140-145. DOI: 10.3109/09638288.2012.691939.

19. Mayo NE, Wood-Dauphinee S, Côté R, Durcan L, Carlton J (2002). Activity, participation, and quality of life 6 months poststroke. Arch Phys Med Rehabil 83(8): 1035-1042. DOI: 10.1053/apmr.2002.33984.

20. McDowell I (2006). Measuring health: a guide to rating scales and questionnaires. Oxford: University Press, USA, $1006 \mathrm{p}$.

21. Peixoto B, Silva S, Carreira S, Sousa D, Rezende V, Teixeira A (2017). Quality of life predictors after first stroke: A study with post-acute patients. Neurol Psychiatry Brain Res 23: 10-15. DOI: 10.1016/j.npbr.2016.11.003.

22. Post MW, Boosman H, Van Zandvoort MM, Passier PE, Rinkel GJ, Visser-Meily JM (2011). Development and validation of a short version of the Stroke Specific Quality of Life Scale. J Neurol Neurosurg Psychiatry 82(3): 283-286. DOI: 10.1136/ jnnp.2009.196394.

23. Rachpukdee S, Howteerakul N, Suwannapong N, TangAroonsin S (2013). Quality of life of stroke survivors: a 3-month follow-up study. J Stroke Cerebrovasc Dis. 22(7): e70-78. DOI: 10.1016/j.jstrokecerebrovasdis.2012.05.005.

24. Rafsten L, Danielsson A, Sunnerhagen KS (2018). Anxiety after stroke: a systematic review and meta-analysis. J Rehabil Med 50(9): 769-778. DOI: 10.2340/16501977-2384.

25. Sadlonova M, Wasser K, Nagel J, Weber-Krüger M, Gröschel S, Uphaus T, et al. (2021). Health-related quality of life, anxiety and depression up to 12 months post-stroke: Influence of sex, age, stroke severity and atrial fibrillation - 
A longitudinal subanalysis of the Find-AFRANDOMISED trial. J Psychosom Res 142: 110353. DOI: 10.1016/j. jpsychores.2020.110353.

26. Selvaraj S, Arora T, Casameni Montiel T, Selvaraj S, Arora T, Casameni Montiel T, et al. (2021). Early screening for poststroke depression, and the effect on functional outcomes, quality of life and mortality: a protocol for a systematic review and meta-analysis. BMJ Open 11: e050451. DOI: 10.1136/ bmjopen-2021-050451.

27. Tabachnick BG, Fidell LS (2007). Using multivariate statistics (5th ed.). Allyn \& Bacon/Pearson Education.

28. Thomas SA, Lincoln NB (2006). Factors relating to depression after stroke. Br J Clin Psychol 45(1): 49-61. DOI: 10.1348/014466505X34183.
29. Tóthová V, Bártlová S, Dolák F, Kaas J, Kimmer D, Maňhalová J, et al. (2014). Quality of life in patients with chronic diseases. Neuro Endocrinol Lett 35(Suppl. 1): 11-18.

30. Towfighi A, Ovbiagele B, El Husseini N, Hackett ML, Jorge RE, Kissela BM, et al. (2017). Poststroke depression: a scientific statement for healthcare professionals from the American Heart Association/American Stroke Association. Stroke 48(2): e30 e43. DOI: 10.1161/STR.0000000000000113.

31. Watanabe $Y$ (2005). Fear of falling among stroke survivors after discharge from inpatient rehabilitation. Int J Rehabil Res 28(2): 149-152. DOI: 10.1097/00004356-200506000-00008.

32. Zigmond AS, Snaith RP (1983). The hospital anxiety and depression scale. Acta Psychiatr Scand 67(6): 361-370. DOI: $10.1111 /$ j.1600-0447.1983.tb09716.x. 